УДК 342.9

DOI 10.31733/2078-3566-2021-2-143-148

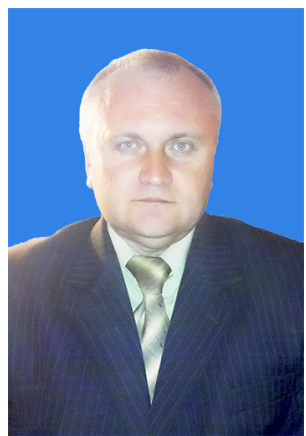

\section{Євген КУРІННИЙ}

доктор юридичних наук, професор

(Запорізький національний університет)

Висвітлено актуальну проблему - особливість вивчення інтересу як категорії адміністративного права України. Розглянуто питання сутності та змісту цього правового терміна та його органічного зв'язку з такою важливою категорією, як «суспільні потреби». Пропоновано власне уніфіковане визначення «суспільних інтересів», обгрунтовано доцільність обрання універсального підходу для подальшого вивчення питань «інтересу» як категорії адміністративного права.

Ключові слова: інтерес, адміністративне право, публічне право, суспільні потреби, публічні інтереси, суспільні інтереси.

Постановка проблеми. Інтерес як категорія вітчизняного права та адміністративного права зокрема є достатньо вживаним у соціальній практиці та одночасно маловивченим у теоретичному плані поняттям, яке незважаючи на свою певну суб'єктивну прихованість, відіграє вирішальну роль у змісті та результатах будь-яких суспільних відносин. Особливо це стосується правовідносин, що виникають у важливих сферах, як-от економіка, національна безпека, оборона, громадський порядок, освіта, охорона здоров'я, безпосереднє належне функціонування яких забезпечується нормами такої фундаментальної галузі вітчизняного права, як адміністративне право.

Дійсно, світом правлять інтереси, у межах конкретного державного утворення його уряд та інші керівні інститути теж реалізують групи численних інтересів у найбільш важливих, значущих для країни (наприклад, зазначених вище) соціальних складових. Коли зміст згаданих інтересів базується на об’єктивно наявних суспільних потребах, для відповідної держави у разі відсутності несприятливих чинників (війни, природних катаклізмів або пандемій) - гарантованим є стабільний національний розвиток та добробут. На випадок невміння формувати відповідні інтереси на основі наявних потреб або ігнорування виконання цього найважливішого владного завдання, така держава фактично $є$ неспроможною реалізовувати покладені на неї основні керівні функції та соціальні завдання, вона поволі набуває статусу нетипової, що рано чи пізно призводить до внутрішніх потрясінь (економічного, соціально-політичного характеру) або зовнішньої експансії (зокрема й військової) з боку більш потужних та агресивних країн світу.

На жаль, ті несприятливі обставини, в яких зараз опинилася наша Батьківщина, слугують прикладом другого (негативного) варіанта втілення в життя більшості суспільних потреб через відповідні сформовані та забезпечені правом інтереси.

На підтвердження цієї тези можна навести не один десяток фактів, однак за умов лемітованості обсягу цієї праці обмежимося тільки найбільш характерними. Зокрема, через завершення 31 січня 2021 року строку придатності вакцини БЦЖ, закупленої за кошти держбюджету, в Україні з лютого поточного року новонароджені не прищеплювалися від туберкульозу. За повідомленням міністра охорони здоров'я Максима Степанова, Дитячий фонд ООН (ЮНІСЕФ) має поставити в Україну нову партію вакцин проти туберкульозу (БЦЖ) у середині березня 2021 року [1]. Другий приклад, пов'язаний з енергетичною безпекою нашої держави і стосується того, що з лютого 2021 року Україна відновила імпорт електроенергії 3 Росії. На думку експертів, цей крок свідчить про кризу управління у зазначеній сфері та поя-

(C) Курінний Є. B., 2021

ORCID iD: https://orcid.org/0000-0002-3069-3405

anastasiaeland@gmail.com 
ви ще одного важеля тиску на Україну [2]. Третій факт стосується зменшення фінансування Збройних сил України у поточному році. Згідно із схваленим Верховною Радою України 15 грудня 2021 року Державним бюджетом видатки для Міністерства оборони України передбачено у сумі 117,7 млрд грн, що на 0,5 млрд грн менше проти остаточної версії оборонного бюджету 2020 року, показник якого на 15,3 \% перевищував видатки на оборону у 2019 році [3].

Викладене вище свідчить про неналежну реалізацію суспільних потреб у сфері охорони здоров'я, паливно-енергетичного комплексу та оборони. Відповідні три різновиди інтересу не набули свого своєчасного та повного втілення у життя, а отже, зробили наше суспільство та державу ще більш вразливими, залежними та незахищеними. Наведені приклади стосуються діяльності уряду та його складових, функціонування яких має переважно адміністративно-правове забезпечення та безпосередньо пов'язане з таким поняттям, як інтерес (публічний, суспільний, державний, національний).

Аналіз публікацій, в яких започатковано вирішення цісї проблеми. Питання інтересу як категорії українського адміністративного права неодноразово були предметом уваги окремих вітчизняних науковців. Теоретичною основою цієї роботи можна вважати оригінальні думки та наукові доробки визнаних метрів української адміністративно-правової науки, як-от А. Б. Авер'янов, Ю. П. Битяк, І. П. Голосніченко, Р. А. Калюжний, Т. О. Коломоєць, В. К. Колпаков.

Однак належно обгрунтованої позиції стосовно поняття й сутності аналізованої категорії та оптимального підходу щодо відповідних досліджень й досі не сформовано, тому подальший розгляд наведених проблем у контексті реформування українського адміністративного права є метою цієї публікації.

Виклад основного матеріалу. Треба зазначити, що інтерес в адміністративному праві має власні характерні ознаки, що випливають 3 властивостей адміністративно-правових відносин. Водночас вирішальною особливістю адміністративно-правових відносин $є$ те, що однією із сторін завжди є носій юридично-владних повноважень щодо інших суб'єктів, якими його наділяють адміністративно- правові норми.

Адміністративно-правові відносини формуються, як правило, в особливій сфері суспільного життя - публічному (державному і самоврядному) управлінні, насамперед у зв'язку iз здійсненням органами виконавчої влади своїх владно-розпорядчих функцій. Ця особливість адміністративно-правовідносин прямо випливає із змісту предмета адміністративно-правового регулювання [4, с. 178].

Тобто домінуючий інтерес, який втілюється в життя під час адміністративно-правових відносин, повинен мати публічне, а точніше, суспільне (державне, національне) походження, в основі якого лежать відповідні не меркантильно-корисливі мотиви окремої особи (клану або групи), а мотиви усвідомлення і бажання з боку владних суб'єктів повної та своєчасної реалізації об'єктивно наявних суспільних потреб, що мають адміністративно-правову нормативну фіксацію.

В одному з об’ємних тлумачних словників української мови під інтересом пропонується розуміти: увага до кого-, чого-небудь, зацікавленість кимось, чимось; цікавість, захоплення; вага, значення; те що найбільш цікавить кого-небудь, що становить зміст чиїхось думок і турбот; прагнення потреби; те, що йде на користь кому-, чому-небудь, відповідає чиїмось прагненням, потребам [5, с. 37].

У Новому тлумачному словникові української мови потреба визначається як: необхідність у кому-, чому-небудь, що вимагає задоволення; те, без чого не можна обійтись; вимоги, які необхідно задовільнити; запити [6, с. 636-637].

На перший погляд, наведені роз'яснення слів інтерес та потреба є дуже близькими, можна сказати схожими. I все ж, між ними є суттєві відмінності: якщо перше - це увага до кого-, чого-небудь, зацікавленість кимось, чимось, прагнення потреби, то друге - це необхідність у кому-, чому-небудь; те, без чого не можна обійтись; вимоги, які необхідно задовільнити. 3 такого порівняння можна припустити, що потреба $\epsilon$ первинною до інтересу і навпаки інтерес $\epsilon$ вторинним до потреби. Інтерес завжди усвідомлений та вмотивований, тому він $є$ завжди суб'єктивним, зі свого боку, потреба має об'єктивний характер, і щоб ії реалізувати не завжди необхідно усвідомлювати ії (приклад з природними, фізіологічними потребами немовлят).

У частках соціального життя, що підлягають нормативно-правовому забезпеченню, реалізуються дві групи інтересів, які мають кореспондуватися із загальними (публічними) потребами-інтересами та для яких така умова не є обов’язковою. Прикладом першого різновиду інтересів може слугувати навчання правилам дорожнього руху з наступним отриманням документа (прав) на керування транспортним засобом. Другий приклад може стосуватися факту безпосередньої купівлі автомобіля, у цьому разі у змісті безпосередніх цивільно-пра- 
вових відносин не буде превалювання публічних потреб-інтересів, навпаки пріоритетними $є$ приватні інтереси конкретної фізичної особи, а ось коли відбувається реєстрація придбаного авто, знову домінуючими у відповідних правовідносинах будуть публічні потреби-інтереси.

Незважаючи на увагу з боку окремої групи науковців, процес вивчення такої відносно нової категорії українського адміністративного права, як «інтерес» навряд можна визнати завершеним. Досі актуальними залишаються питання щодо суспільної цінності та призначення згаданого терміна, його співвідношення з такими важливими категоріями, як суспільні «потреби» та «відносини», також необхідно уточнити етимологічні аспекти, пов'язані $з$ широким використанням окремих термінологічних адміністративно-правових словосполучень з присутністю категорії «інтерес».

Серед адміністративно-правових норм, що становлять чинне вітчизняне законодавство, достатньо часто можна зустріти дефінітивні словосполучення з використанням слова інтерес. Зокрема, у нормах передбачених: частиною 1 статті 19 Закону України «Про Кабінет Міністрів України» від 27 лютого 2014 року, вказано, що діяльність уряду має спрямовуватись на забезпечення інтересів Українського народу; у пункті 2 частини 1 статті 2 Закону України «Про національну поліцію України» від 20 серпня 2015 року зазначено, що одним із завдань поліції є охорона інтересів суспільства і держави; частиною 3 статті 3 Закону України «Про національну безпеку» від 21 червня 2018 року наводиться перелік складових, що становлять сферу національних інтересів України; частиною 3 статті 3 Закону «Про прокуратуру» від 14 жовтня 2014 року викладені умови представництва прокурором в суді у разі порушення або загрози порушення інтересів держави; підпункт «в» пункту 2 частини 5 статті 328 Кодексу адміністративного судочинства України від 14 червня 2018 року, передбачає можливість касаційного оскарження судового рішення, якщо справа становить значний суспільний інтерес або пункт 3 частини 2 статті 6 Закону України «Про доступ до публічної інформації» від 13 січня 2011 року, який фіксує одну з умов обмеження доступу до інформації, коли шкода від оприлюднення такої інформації переважає суспільний інтерес в іiі отриманні.

Незважаючи на те що словосполучення «публічний інтерес» майже не використовується у нормах чинного адміністративного законодавства, ця абревіатура достатньо широко популяризується у відповідних наукових доробках, пов'язаних з адміністративно-правовою тематикою, та має декілька варіантів свого визначення. В. Галунько під публічним інтересом пропонує розуміти важливі для великої кількості фізичних та юридичних осіб потреби, які відповідно до законодавчо встановленої компетенції забезпечуються публічною адміністрацією [7, с. 181], а Л. Золотухіна уявляє публічний інтерес як сукупність потреб, прагнень учасників суспільних відносин, що визначаються державою, реалізація яких гарантується засобами публічного управління та сприяє забезпеченню прав і свобод людини [8, с. 143].

Наведені визначення можна вважати лише окремими спробами формування повноцінного наукового підходу щодо розуміння та фіксації такої категорії, як публічний (суспільний) інтерес $з$ подальшим широким використанням іiі поряд з іншими термінами у відповідному арсеналі адміністративно-правових категорій. Зокрема, у викладених вище інтерпретаціях використання терміна «потреби» вимагає уточнення, що це не просто потреби, а усвідомлені публічні (суспільні) потреби, бо, як відомо, інтерес - це достатньо суб'єктивне поняття, яке є результатом усвідомлення необхідності досягнення, отримання чогось-когось, тим чи іншим суб'єктом у той чи інший час, потреба навпаки - об'єктивне явище, що певний час або назавжди може лишатися поза свого усвідомлення. Наприклад, у сучасній Україні вже тривалий час існує суспільна потреба суттєвого поліпшення стану довкілля, яка зумовлена насамперед критичними показниками забруднення повітря, води, грунтів тощо. Чи належно є усвідомленою ця потреба, чи є сформованим відповідний суспільний інтерес, чи готовий він до своєї реалізації? Відповідь - зазначений різновид інтересу знаходиться на стадії формування, тобто не має свого належного суспільного усвідомлення, законодавчої фіксації та готовності до втілення у життя.

Наступними спірними моментами запропонованих визначень публічного інтересу в адміністративному праві є тези про те, що: вони забезпечуються публічною адміністрацією (перший варіант), та їх реалізація гарантується засобами публічного управління (другий варіант). У першому випадку автору з огляду на те, що відповідні інтереси можуть забезпечуватись не тільки публічними адміністраціями, а також судом, прокуратурою або окремими громадськими організаціями, вартувало б додати одне слово «переважно» (переважно забезпечуються). У другому варіанті, з огляду на поліструктурність предмета вітчизняного права, словосполучення «їх реалізація гарантується засобами публічного управління» краще замінити на «їх реалізація відбувається за допомогою широкого спектра адміністративно-правового арсеналу», що більше відповідатиме реаліям сьогодення, характерною ознакою якого $є$ можливість використання не тільки управлінсько-примусового інструментарію, а й засобів 
регуляторно-диспозитивного характеру.

Хоча на законодавчому рівні поки що немає визначення «публічний інтерес», на офіційному, владному рівні воно певним чином присутнє. Зокрема, у постанові Великої Палати Верховного Суду України від 13 лютого 2019 р. у справі № 810/2763/17 публічний інтерес визначено як важливі для великої кількості фізичних і юридичних осіб потреби, які відповідно до законодавчо встановленої компетенції забезпечуються суб' єктами публічної адміністрації. Тобто публічний інтерес є нічим іншим, як певною сукупністю приватних інтересів [9].

Як бачимо, наведене визначення дуже кореспондується 3 варіантом В. Галунька 3 єдиною відмінністю, що до нього додана згадка про приватні інтереси. На наш погляд, це доповнення не є бездоганним та потребує докладного вивчення у процесі подальших наукових досліджень порушеної проблеми. Як аргументацію цієї тези можна навести приклад 3 наявністю обов'язкового дозволу на мисливську зброю або відповідної реєстрації та прав на водіння автомобілем для конкретного власника фізичної особи, в якої виник інтерес стати мисливцем або водієм. Тобто у цих випадках конкретний приватний інтерес має відповідати зафіксованому у чинних нормах права публічним (суспільним) інтересам. Якби не ці обов'язкові імперативні умови, запроваджені з огляду на набуті тривалі соціальні практики, та чи інша приватна особа реалізовувала б свій конкретний інтерес у найбільш спрощеній та найбільш вигідній для себе малоформалізованій процедурі.

Також згадане вище твердження, що публічний інтерес є нічим іншим, як певною сукупністю приватних інтересів, означає фактичну легітимізацію підміни змісту істинних публічних (суспільних) інтересів, приватними, груповими інтересами представників домінуючої в сучасній українській державі кланово-олігархічної кумівсько-сімейної системи (наприклад, непрозоре формування комунальних тарифів або купівлі вугілля за схемою Роттердам плюс). Суспільний (публічний) інтерес має дуже складний механізм свого формування, у функціонуючих зараз розвинутих світових демократіях вирішальне місце у цих процесах займають політичні партії (насамперед ті, що мають своє представництво у парламенті та уряді держави), також вагомий вплив на нормативне закріплення тих чи інших загальних інтересів може відбуватися з боку профспілок, інших громадських організацій та місцевих самоврядних органів. У країнах, які не мають сталих демократичних інститутів та традицій, формування публічних інтересів може поєднуватися з непоодинокими конфліктами та суперечностями (наприклад, важко знайти єдиний зміст суспільного інтересу як поєднання приватних інтересів, коли урядом ініціюється процедура масового заповнення декларацій про доходи, при можливості фактичного звільнення від цього значної частини представників великого бізнесу, які свої багатомільйонні доходи можуть цілком легально переводити в офшори, і тим самим уникати оподаткування).

Повертаючись до визначення публічних інтересів та їх різновидів, треба зазначити, що в чинному українському законодавстві можна зустріти лише тільки визначення національних інтересів України, яке міститься у пункті 10 частині 1 статті 1 Закону України «Про національну безпеку України» від 21 червня 2018 року, під згаданими інтересами розуміють життєво важливі інтереси людини, суспільства і держави, реалізація яких забезпечує державний суверенітет України, іiі прогресивний демократичний розвиток, а також безпечні умови життєдіяльності і добробут ії громадян.

Для справедливості треба зазначити, що у частині 2 статті 29 Закону «Про інформацію» від 2 жовтня 1992 року зафіксовано, що предметом суспільного інтересу вважається інформація, яка свідчить про загрозу державному суверенітету, територіальній цілісності України; забезпечує реалізацію конституційних прав, свобод і обов'язків; свідчить про можливість порушення прав людини, введення громадськості в оману, шкідливі екологічні та інші негативні наслідки діяльності (бездіяльності) фізичних або юридичних осіб тощо.

3 метою упорядкування уяви про соціально значущі інтереси, на нашу думку, треба чітко визначити їх видову градацію (систему) та, використовуючи їі, обрати найбільш прийнятний, універсальний різновид, на основі якого не тільки буде формуватися подальше вітчизняне законодавство, а й наступні науково-теоретичні дослідження, зокрема у сфері науки адміністративного права.

Як показує досвід, найбільш широко вживаними видами загальних (соціальних) інтересів у правовій практиці та науці є: публічні, суспільні, державні та національні інтереси. Дані різновиди дуже пов'язані один з одним, мають багато спільного (наприклад, публічні та суспільні вважаються майже синонімами), і водночас суттєво відрізняються між собою, особливо за обсягом та змістом (суспільні є більш об'ємними за державні та національні, державні - похідні від суспільних, а національні можуть бути не завжди за умов наявності конкретної держави). Зважаючи на ці чинники, система загальних інтересів, на наш погляд, 
повинна мати таку конструкцію: публічні; суспільні; національні; державні інтереси.

На нашу думку, родовими серед наведених чотирьох різновидів загальних інтересів можна визнати публічні та суспільні інтереси, а роль домінуючої категорії (понятійної основи) у правознавстві повинна належати суспільним інтересам. Головними аргументами такої позиції $є$ : а) більш чітка визначеність та конкретність між словами «суспільний» та «публічний» (суспільство і публіка) на користь першого; б) дотримання неформальних вітчизняних правових традицій та практик, де у ролі засадничих $є$ такі поняття, як «суспільні відносини», «суспільні потреби»; в) вирішальна роль громадянського суспільства у процесах усвідомлення об'єктивно наявних суспільних потреб $з$ наступним переформатуванням їх у відповідні інтереси; г) універсальність словосполучення «суспільний інтерес», яке можна застосовувати у будь-якій галузі українського права (насамперед так званого публічного права); д) найбільш поширене використання терміна «суспільні інтереси» у чинному законодавстві України.

Основними аксіологічними складовими суспільного інтересу, що спонукатиме до його подальшого дослідження та широкого практичного використання, $є$ перевірка наявності обов'язкового зв'язку між конкретною суспільною потребою та похідним від неї суспільним інтересом, що має бути закріплений у відповідних правових нормах, та визначення мотиву поведінки чиновництва у безпосередніх правовідносинах, що забезпечуються нормами адміністративного та інших різновидів галузей права владно-управлінської спрямованості (фінансового, земельного, екологічного права тощо).

Після фіксації основних ціннісних ознак суспільних інтересів під ними пропонується розуміти - інституціонально усвідомлені та визначені об’єктивно наявні суспільні потреби, найбільш значущі з яких повинні мати нормативно-правову фіксацію та реалізовуватися у життя за участю різноманітних структур влади з метою забезпечення сталого розвитку суспільства і держави, а також високого рівня добробуту громадян.

Запропоноване визначення суспільних інтересів, на нашу думку, є достатньо універсальним і може набути своє гідне місце в понятійному арсеналі будь-якої галузі права, зокрема й українського адміністративного права.

Висновки. На підставі викладеного можна констатувати, що $є$ два підходи вирішення питань інтересу як категорії адміністративного права - виокремлений (сепаратний) та універсальний. Під час першого його прихильники намагаються визначити найбільш характерні ознаки інтересу, що притаманні тільки для сфери застосування адміністративно-правового інструментарію, та надають перевагу такому терміну, як «публічні інтереси». В умовах другого варіанта, навпаки, виробляється уніфікований підхід для визначення інтересу, який буде прийнятний для будь-якої галузі права, та як найбільш прийнятну та домінуючу категорію пропонується застосовувати словосполучення «суспільні інтереси». На нашу думку, більш перспективним $є$ універсальний підхід, бо він унеможливлює можливі непорозуміння між науковцями-репрезентантами різних галузей вітчизняного права та дає змогу уніфікувати правову термінологію, в якій використовується така категорія, як інтерес.

\section{Список використаних джерел}

1. https://ua.interfax.com.ua/news/general/727581.html.

2. https://www.dw.com/uk/відновлення-імпорту-струму-з-росії-хто-навіщо-та-які-наслідки/a-5645815.

3. https://armyinform.com.ua/2020/12/yaki-napryamky-finansuvannya-v-oboronnomu-byudzheti-2021-u-prioryteti.

4. Адміністративне право України. Академічний курс : підручник : у 2-х т. / ред. колегія: В. Б. Авер'янов. Київ : Юридична думка, 2004. Т. 1: Загальна частина. 584 с.

5. Словник української мови : в 11 т. Т. 4. 1973.

6. Новий тлумачний словник української мови : в 4 т. Т. 3. 1998.

7. Галунько В. О. Публічний інтерес в адміністративному праві. Форум права. 2010. № 4. C. $178-182$.

8. Золотухіна Л. О. Феномен публічного інтересу як категорії адміністративного права : монографія. Херсон : Видавничий дім «Гельветика», 2019. 478 с.

9. Постанова Великої Палати Верховного Суду України від 13 лютого 2019 р. у справі № 810/2763/17. Сдиний державний реєстр судових рішень. URL http: // reyestr.court.gov.ua/ Review/79883398. 


\section{References}

1. https://ua.interfax.com.ua/news/general/727581.html [in Ukr.].

2. https://www.dw.com/uk/відновлення-імпорту-струму-з-росії-хто-навіщо-та-які-наслідки/a-5645815 [in Ukr.].

3. https://armyinform.com.ua/2020/12/yaki-napryamky-finansuvannya-v-oboronnomu-byudzheti-2021u-prioryteti [in Ukr.].

4. Administratyvne pravo Ukrainy. Akademichnyi kurs [Administrative law of Ukraine. Academic course] : pidruchnyk : u 2-kh t. / red. kolehiia: V. B. Averianov. Kyiv : Yurydychna dumka, 2004. Vol. 1: Zahalna chastyna. 584 p. [in Ukr.].

5. Slovnyk ukrainskoyi movy [Dictionary of the Ukrainian language] : v 11 t. T. 4.1973 [in Ukr.].

6. Novyi tlumachnyi slovnyk ukrayinskoyi movy [New explanatory dictionary of the Ukrainian language] : v 4 t. T. 3. 1998 [in Ukr.].

7. Halunko V. O. (20100 Publichnyi interes v administratyvnomu pravi [Public interest in administrative law]. Forum prava, no 4, pp. 178-182 [in Ukr.].

8. Zolotukhina L. O. (2019) Fenomen publichnoho interesu yak katehorii administratyvnoho prava [The phenomenon of public interest as a category of administrative law] : monohrafiia. Kherson: Vydavnychyi dim «Helvetyka». 478 p. [in Ukr.].

9. Postanova Velykoyi Palaty Verkhovnoho Sudu Ukrayiny vid 13 liutoho 2019 r. u spravi № 810/2763/17 [Resolution of the Grand Chamber of the Supreme Court of Ukraine of February 13, 2019 in the case № 810/2763/17]. Yedynyi derzhavnyi reiestr sudovykh rishen. URL : http: // reyestr.court.gov.ua/ Review/79883398 [in Ukr.].

ABSTRACT
Yevhen Kurinnyi. Interest as a category of administrative law of Ukraine. The article deals with peculiarities of interest as a category of administrative law of Ukraine. The author has emphasized that interest as a category of domestic law and administrative law, in particular, is a well-used concept in social practice and at the same time poorly studied in theoretical terms. This is especially true of legal relations in such important areas as the economy, national security, defense, public order, education, health care, the direct proper functioning of which is ensured by the rules of such a fundamental area of domestic law as administrative law.

It has been noted that the interest in administrative law has its own characteristics, arising from the properties of administrative-legal relations. At the same time, the decisive feature of administrativelegal relations is that one of the parties is always the bearer of legal authority over other subjects, which it is endowed with administrative-legal rules.

The main axiological components of the public interest, which encourages its study and wide practical use, is to verify the existence of a mandatory link between a specific public need and the resulting public interest, which should be enshrined in relevant legal rules and determine the motive for bureaucracy in direct legal relations provided by the norms of administrative and other types of branches of law of power-management orientation (financial, land, environmental law, etc.).

The author has proposed to understand public interests as institutionally aware and defined objectively existing social needs, the most important of which must have a legal basis and be implemented with the participation of various government agencies to ensure sustainable development of society and the state, as well as citizens' high welfare .

He states that there are two approaches to resolving issues of interest as a category of administrative law - individual (separate) and universal. In the first, its supporters try to identify the most characteristic features of interest, which are inherent only in the scope of administrative and legal tools and prefer such a term as "public interest". In the second option, on the contrary, a unified approach to determining the interest is developed, which will be acceptable for any branch of law, and as the most acceptable and dominant category, it has been proposed to use the phrase "public interest". A universal approach is seen as more promising, because it eliminates possible misunderstandings between scholars representing different branches of domestic law and provides an opportunity to unify the legal terminology in which such a category as interest is used.

Keywords: interest, administrative law, public law, public needs, public interests, social interests. 